\title{
Field Life-Tables and Key Mortality Factors of Plutella xylostella Infesting Sole and Onion Intercropped Cabbage
}

\author{
G. Aravindarajan ${ }^{1 *}$, S.R. Dhandge ${ }^{1}$, T. Anandmurthy ${ }^{1}$ and J.E. Wandhekar ${ }^{2}$ \\ ${ }^{1}$ Department of Entomology, Junagadh Agricultural University, Junagadh, India \\ ${ }^{2}$ Department of Agricultural Entomology, College of Agriculture, Latur, Vasantrao Naik \\ Marathwada Krishi Vidhyapeth, Parbhani, India \\ *Corresponding author:
}

\begin{tabular}{|c|c|}
\hline \multicolumn{2}{|r|}{ A B S T R A C T } \\
\hline & \multirow{6}{*}{$\begin{array}{l}\text { The present investigation was made to study the field life-tables and key mortality factors } \\
\text { of Plutella xylostella infesting sole and onion intercropped cabbage. P. xylostella passed } \\
\text { through } 3 \text { and } 2 \text { generations on sole and onion intercropped cabbage, respectively during } \\
\text { rainy season } 2011 . \text { On sole cabbage the highest mortality of early and late instar larvae of } \\
P \text {. xylostella in first, second and third generations during rainy season } 2011 \text { was observed } \\
\text { to be } 33.90,37.62 \text { and } 32.73 \text { per cent due to Cotesia vestalis followed by unknown causes } \\
\text { ( } 10.10,13.52 \text { and } 0.00 \text { per cent). While in onion intercropped cabbage, the highest } \\
\text { mortality of early and late instar larvae of } P \text {. xylostella was observed to be } 37.69 \text { and } 35.25 \\
\text { per cent due to Cotesia vestalis followed by unknown causes } 14.62 \text { and } 8.10 \text { per cent in } \\
\text { first and second generations, respectively. Pupal mortality was observed to the extent of } \\
6.08 \text { and } 13.61 \text { per cent in first and second generations, respectively due to Tetrastichus sp. } \\
\text { One generation of } P \text {. xylostella was reduced on onion intercropped cabbage as compared } \\
\text { to sole crop of cabbage. During rainy seasons of } 2011 \text {, the trend indices of } P \text {. xylostella } \\
\text { were } 0.52,0.29 \text { and } 0.00 \text { in first, second and third generations, respectively on sole } \\
\text { cabbage and } 0.42 \text { and } 0.00 \text { in first and second generations, respectively on onion } \\
\text { intercropped cabbage. }\end{array}$} \\
\hline & \\
\hline $\begin{array}{l}\text { Plutellax ylostella, } \\
\text { field life-tables, } \\
\text { Key mortality } \\
\text { factors, } \\
\text { Cabbage, Onion }\end{array}$ & \\
\hline Article Info & \\
\hline $\begin{array}{l}\text { Accepted: } \\
04 \text { April } 2017 \\
\text { Available Online: } \\
10 \text { May } 2017\end{array}$ & \\
\hline & \\
\hline
\end{tabular}

\section{Introduction}

The graph of world's population has been increasing continuously and as a result, food requirement has also increased. Agriculture takes a vow of providing food to all. Vegetables play a vital role in ensuring the health and nutritional security of human beings in addition to improve the economy of the people of the country. Cabbage (Brassica oleracea var capitata L.) is a cold loving plant and is supposed to have originated in Mediterranean region. This crop is grown in China, India, Poland, Rumania, U.S.A.,
Canada etc. In India, it is grown mainly in West Bengal, Bihar, Assam, Karnataka, Maharashtra, Gujarat and Tamil Nadu. It is grown over an area of about 3.79 lakh hectares and production is about 85.81 lakh metric tonnes with productivity of 22.0 metric tonnes per hectare in India. In Maharashtra the annual production of cabbage was 1.55 lakh metric tonnes from an area of 7.15 thousand hectares in 2014-15 with a productivity of 26.0 metric tonnes per hectare (Anonymous, 2017). 
Cabbage has been reported to be attacked by number of insects-pests. More than 27 species of insect-pests were recorded on cabbage in India (Bhatia and Verma, 1993). The insectpests viz., diamondback moth (Plutella xylostella Linnaeus), cabbage butterfly (Pierisbrassicae Linnaeus), tobacco caterpillar (Spodopteralitura Fabricius), cabbage semilooper (Trichoplusiani Hubner), aphids (Brevicoryne brassicae Linnaeus), painted bug (Bagradacruciferarum Kirkaldy), cabbage leaf webber (Crocidolomiabinotalis Zeller), cabbage borer (Hellulaundalis Fabricius), cabbage flea beetle (Phyllotretacruciferae Goeze) and Bihar hairy caterpillar (Spilosomaobliqua Walk) are observed commonly on cabbage in different seasons and cause considerable losses.

The diamond back moth, Plutella xylostella (L.) (Lepidoptera: Plutellidae), is an oligophagous pest of plants in the family Brassicaceae (Furlong et al., 2013). Diamondback moth is cosmopolitan in distribution (Hill, 1975 and Zhang, 1994) and causes serious economic losses worldwide (Jankowska \& Wiech, 2006). Worldwide, this pest generates losses of over $80 \%$ (U.S. $\$ 4$ to U.S. $\$ 5$ billion) in annual crop production (Verkerk \& Wright, 1996; Sarfraz et al., 2005; Zalucki et al., 2012). In India, it was first recorded on cruciferous vegetables in 1914 (Fletcher, 1914) and now it is distributed throughout the country. Pandey and Raju (2003) found diamondback moth as most devastating pest of cole crops in the states of Punjab, Haryana, Himachal Pradesh, Uttar Pradesh, Bihar, Maharashtra, Tamil Nadu and Karnataka. It has a pest status of national importance. Annual cost of managing this pest was estimated to be 1 billion U.S. dollars (Talekar and Shelton, 1993). Krishnakumar et al., (1983) estimated about 52 per cent losses in marketable yield due to the diamondback moth. The losses could be more than 80 per cent under severe infestation of diamondback moth on cabbage (Cheliah and Srinivasan, 1986). Sarfraz \& Keddie (2005) reported the physiological capacity of $P$. xylostellato detoxify glucosinolates, the natural defense system of Brassicaceae.

Life-tables and key mortality factors are one of the tools most useful in the study of insect population dynamics. Field life-tables and key mortality factors may be analysed to determine what stage in the life cycle of an insect contributes the most when series of life-tables are available (Atwal and Bains, 1974). The construction of field life-tables provides a useful approach to pest management strategies. Life-tables are particularly well suited to the population and analysis of population trends (Harcourt, 1970). A key factor is any biological or environmental condition associated with mortality that is useful in predicting future trend in a population (Morris, 1959). The uses of field life-tables have been made recently for studying the natural population of insect pests when the environmental parameters are related to several causes of mortality of pests. The field life-tables form a budget of the successive process that operates in a given population (Harcourt, 1966 and 1969).

Recently, emphasis is being given on ecological basis of pest control based on suitable integrated pest management strategies. As cabbage crop is heavily infested by Plutella xylostella, it is necessary to study the effect of intercropping of onion with cabbage on population fluctuations and field life-tables of lepidopterous pests in comparison to sole crop of cabbage.

\section{Materials and Methods}

The investigations on field life-tables and key mortality factors of Plutella xylostella infesting sole and onion intercropped cabbage 
were carried out at the Department of Agricultural Entomology, College of Agriculture, Latur during rainy season 2011.

\section{Experimental details}

The non-replicated field experiment comprising eighty quadrats of $1.80 \times 1.80 \mathrm{~m}^{2}$ size each was during rainy season, 2011 to investigate and prepare field life-tables of Plutella xylostella infesting sole and onion intercropped cabbage. The cabbage variety, Golden acre was transplanted at the spacing of $60 \times 60 \mathrm{~cm}^{2}$ in eighty quadrats and out of these forty quadrats were intercropped with onion variety, $\mathrm{N}-53$ with spacing of $10 \times 20$ $\mathrm{cm}^{2}$. The field experiment was conducted under pesticide free condition.

\section{Field generation studies}

After transplanting four weeks old seedlings, frequent field visits were made in order to record the first incidence (egg stage) of Plutella xylostella of cabbage. After having made frequent field visits at regular intervals, the known number of eggs as a start of first generation of the pest were collected along with the plant material. After hatching of these eggs, the larvae were reared on cabbage in clean plastic boxes of $5 \times 5 \times 5 \mathrm{~cm}$ size till the cessation of pest population in the field. This culture was considered as a check culture for deciding the number of regular generations of pests under field conditions.

The sampling of early and late instar larvae was done on the basis of development of pests in the laboratory reared culture. At each observation, three quadrats from each sole and onion intercropped cabbage were carefully examined twice in a week for the number of larvae of $P$. xylostella. The field collected larvae and pupae were brought to the laboratory and reared on cabbage. This was referred to as a field culture. The food was changed as and when required. The culture was reared till adult emergence.

The observations were made on the larval and pupal parasitism as well as mortality because of unknown reasons and entomopathogens in early and late larval instars and pupal stage as well. An interval of four to six days was provided before sampling of eggs of next generation after the mean adult emergence of previous generation. This period was considered for completion of oviposition by moths of the previous generation.

\section{Preparation of life tables}

The column headings proposed by Morris and Miller (1954) and Harcourt (1969) were used in the life-tables of the present study. Harcourt (1963) had proposed the criteria for filling the data in the life-table for each age interval (stage). The same criteria were used in this study. Trend analysis and generation survival percentage were calculated based on the obtained data.

\section{Results and Discussion}

The studies on field life-tables of Plutella xylostella infesting sole and onion intercropped cabbage was undertaken at the Department of Agricultural Entomology, College of Agriculture, Latur during rainy seasons 2011. The results obtained during the course of experimentation are presented under the following headings:

\section{First Generation}

The results on field life-tables and key mortality factors of $P$. xylostella on sole cabbage and onion intercropped cabbage in first generation during rainy season 2011 are presented in Table 1, 2, 3 and 4. It is evident from Table 1 and 3 that the incidence of $P$. xylostella was first recorded in $33^{\text {rd }}$ 
meteorological week. On sole cabbage, due to sterility 5 per cent eggs did not hatch into the larvae. The mortality of early instar larvae to the extent of 6.87 per cent was observed due to Cotesia vestalis Haliday (Braconidae). However, the mortality of late instar larvae to the extent of 27.03 and 10.10 per cent was observed due to Cotesia vestalis and unknown reasons, respectively. The pupal mortality (7.49 per cent) was observed due to unknown reasons. The negative trend index (0.52) revealed that the mortality factors operated during first generation were effective in suppressing the population of $P$. xylostella in second generation. The generation survival was 0.56 . Table 2 showed that the maximum contribution towards generation mortality came from late instar larvae $(\mathrm{k}=0.1831)$ followed by pupae $(\mathrm{k}=0.0338)$. The total ' $\mathrm{K}$ ' for all life-stages was 0.5712. On onion intercropped cabbage, 5 per cent eggs did not hatch into the larvae due to sterility. The mortality of early (10.18 and 3.78 per cent) and late (27.51 and 10.84 per cent) instar larvae were killed due to Cotesia vestalis and unknown reasons, respectively. The pupal mortality (6.08 per cent) was observed due to Tetrastichus sp (Table 3). The negative trend index (0.42) revealed that the mortality factors operated during first generation were effective in suppressing the population of $P$. xylostella in second generation. Table 4 showed that the maximum contribution towards generation mortality came from late instar larvae $(\mathrm{K}=0.1896)$ followed by early instar larvae $(\mathrm{K}=0.0634)$. The total ' $\mathrm{K}$ ' for all life-stages was 0.6035 .

\section{Second generation}

The results on key mortality factors of $P$. xylostella infesting sole and onion intercropped cabbage for second generation during rainy season 2011 are summarized in Table 5, 6, 7 and 8. The data (Table 5 and 7) revealed that 5 per cent eggs did not hatch into larvae due to sterility in each of the cropping pattern. On sole cabbage early instar larvae to the extent of 8.77 per cent were killed by $C$. vestalis. Whereas, the mortality of late instar larvae to the extent of 28.85 and 13.52 per cent was observed due to $C$. vestalis and unknown reasons. The pupal mortality to the extent of 7.61 and 8.48 per cent was due to Tetrastichus sp. and unknown reasons, respectively. The generation survival was 0.47 . The negative trend index (0.29) revealed that the mortality factors operated during second generation were effective in suppressing the population of $P$. xylostella in third generation. Table 6 showed that the maximum contribution towards generation mortality came from late instar larvae $(\mathrm{K}=$ $0.2109)$ followed by pupal stage $(\mathrm{K}=0.0738)$. The total ' $\mathrm{K}$ ' for all life-stages was 0.6479 . The results on key mortality factors of $P$. xylostella infesting onion intercropped cabbage for second generation (Table 7) revealed that early instar larvae to the extent of 8.10 per cent were killed by unknown reasons. Whereas, the late instar larvae to the extent of 35.25 per cent were parasitized by Cotesia vestalis. The pupal mortality to the extent of 13.61 per cent was due to Tetrastichus sp. The generation survival was 0.51 . Zero trend index indicated that the pest population of $P$. xylostella ceased after second generation. Table 8 showed that the maximum contribution towards generation mortality came from late instar larvae $(\mathrm{K}=0.1887)$ followed by pupal stage $(\mathrm{K}=0.0636)$. The total ' $\mathrm{K}$ ' for all life-stages was 0.6125 .

\section{Third generation}

The results on key mortality factors of $P$. xylostella infesting sole cabbage for third generation during rainy season 2011 are summarized in Table 9 and 10. The data (Table 9 and 10) revealed that 5 per cent eggs did not hatch into larvae due to sterility. On sole cabbage early instar larvae to the extent 
of 15.03 per cent were killed by Cotesia vestalis. The corresponding mortality of late instar larvae was 17.70 per cent. The pupal mortality to the tune of 21.50 per cent was due to Tetrastichus sp. The generation survival was 0.54 . The pest population ceased after third generation (trend index $=$ Zero). It is evident from Table 10 that maximum mortality of $P$. xylostella was observed in pupal stage $(\mathrm{k}=0.1051)$ followed by late instar larvae $(\mathrm{k}=0.0846)$. The total K's was 0.5838 .

The larval parasitoid viz., Cotesia vestalis and pupal parasitoid viz., Tetrastichus sp. were found to be major mortality factors of $P$. xylostella. The larval parasitization of $P$. xylostella on sole and onion intercropped cabbage varied from 32.73 to 37.62 and 35.25 to 37.69 per cent due to $C$. vestalis during rainy season 2011 . While, its pupal mortality due to Tetrastichus sp. ranged from 7.61 to 21.50 and 6.08 to 13.61 per cent. The late larval instar of $P$. xylostella was observed to be parasitized more than its early larval instars. Yadav et al., (1975 and 1979) reported that $P$. xylostella was found to be parasitized to the extent of 66 and 77.7 per cent by Cotesia plutellae during August 1973 and September 1974, respectively.

Table.1 Key mortality factors of $P$. xylostellaon sole cabbage for first generation

\begin{tabular}{|c|c|c|c|c|c|}
\hline Age interval & $\begin{array}{c}\text { Number } \\
\text { alive / ha } \\
\text { at the } \\
\text { beginning } \\
\text { of } x \\
\end{array}$ & $\begin{array}{l}\text { Factors } \\
\text { responsible } \\
\quad \text { for } \mathbf{d}_{\mathbf{x}}\end{array}$ & $\begin{array}{l}\text { Number } \\
\text { dying } \\
\text { during } x\end{array}$ & $\begin{array}{c}d_{x} \text { as } \% \\
\text { of } I_{x}\end{array}$ & $\begin{array}{c}\text { Survival } \\
\text { rate at } \\
\text { age } x\end{array}$ \\
\hline $\mathrm{X}$ & $1_{\mathrm{x}}$ & $d_{x} F$ & $\mathrm{~d}_{\mathrm{x}}$ & $100 q_{x}$ & $S_{x}$ \\
\hline Expected eggs & 15775 & Sterility & 789 & 5.00 & \\
\hline Viable eggs & 14986 & - & & & \\
\hline \multicolumn{6}{|l|}{ Larval population } \\
\hline Early instar larvae $\left(\mathrm{N}_{1}\right)$ & 14986 & Cotesia vestalis & 1029 & 6.87 & 0.93 \\
\hline \multirow[t]{2}{*}{ Late instar larvae } & 13957 & Cotesia vestalis & 3773 & 27.03 & 0.65 \\
\hline & 10184 & $\begin{array}{l}\text { Unknown } \\
\text { reasons }\end{array}$ & 1029 & 10.10 & \\
\hline Pupae & 9155 & $\begin{array}{l}\text { Unknown } \\
\text { reasons }\end{array}$ & 686 & 7.49 & 0.92 \\
\hline Moths & 8469 & $\begin{array}{l}\text { Sex } 50 \% \\
\text { females }\end{array}$ & & & \\
\hline Females x $2\left(\mathrm{~N}_{3}\right)$ & 8469 & $\begin{array}{l}\text { (Reproducing } \\
\text { females= 4234) }\end{array}$ & & & \\
\hline Trend index $\left(\mathrm{N}_{2} / \mathrm{N}_{1}\right)$ & & & 0.52 & - & - \\
\hline \multicolumn{3}{|c|}{ Generation survival $\left(\mathrm{N}_{3} / \mathrm{N}_{1}\right)$} & 0.56 & - & - \\
\hline
\end{tabular}


Table.2 Budget of $P$. xylostella on sole cabbage for first generation

\begin{tabular}{|l|l|l|l|}
\hline \multicolumn{1}{|c|}{ Age interval } & Number / ha & Log No./ha & 'k' values \\
\hline Expected Eggs & 15775 & 4.1979 & - \\
\hline Viable Eggs & 14986 & 4.1756 & 0.0223 \\
\hline Early instar larvae & 14986 & 4.1756 & 0.0000 \\
\hline $\begin{array}{l}\text { After mortality due to parasitoid - Late } \\
\text { instar larvae }\end{array}$ & 13957 & 4.1447 & 0.0309 \\
\hline $\begin{array}{l}\text { After mortality due to parasitoidand } \\
\text { unknown reasons - Pupae }\end{array}$ & 9155 & 3.9616 & 0.1831 \\
\hline $\begin{array}{l}\text { After mortality due to unknown reasons - } \\
\text { Moths }\end{array}$ & 8469 & 3.9278 & 0.0338 \\
\hline Reproducing females & 4234 & 3.6267 & 0.3011 \\
\hline & \multicolumn{3}{|l}{$\mathrm{K}=0.5712$} \\
\hline
\end{tabular}

Table.3 Key mortality factors of $P$. xylostella on onion intercropped cabbage for first generation

\begin{tabular}{|c|c|c|c|c|c|}
\hline Age interval & $\begin{array}{c}\text { Number } \\
\text { alive /ha at } \\
\text { the } \\
\text { beginning } \\
\text { of } x\end{array}$ & $\begin{array}{l}\text { Factors responsible } \\
\quad \text { for } d_{x}\end{array}$ & $\begin{array}{c}\text { No. } \\
\text { dying } \\
\text { during } \\
\quad x\end{array}$ & $\begin{array}{l}d_{x} \text { as } \\
\% \text { of } l_{x}\end{array}$ & $\begin{array}{c}\text { Survival } \\
\text { rate at age } \\
x\end{array}$ \\
\hline $\mathrm{X}$ & $1_{\mathrm{x}}$ & $d_{x} F$ & $d_{x}$ & $100 q_{x}$ & $S_{x}$ \\
\hline Expected eggs & 10631 & Sterility & 531 & 5.00 & \\
\hline Viable eggs & 10100 & - & & & \\
\hline \multicolumn{6}{|l|}{ Larval population } \\
\hline \multirow[t]{2}{*}{$\begin{array}{l}\text { Early instar larvae } \\
\left(\mathrm{N}_{1}\right)\end{array}$} & 10100 & Cotesia vestalis & 1029 & 10.18 & 0.86 \\
\hline & 9071 & Unknown reasons & 343 & 3.78 & \\
\hline \multirow[t]{2}{*}{ Late instar larvae } & 8728 & Cotesia vestalis & 2401 & 27.51 & 0.65 \\
\hline & 6327 & Unknown reasons & 686 & 10.84 & \\
\hline Pupae & 5641 & Tetrastichussp. & 343 & 6.08 & 0.94 \\
\hline Moths & 5298 & Sex $50 \%$ females & & & \\
\hline Females x $2\left(\mathrm{~N}_{3}\right)$ & 5298 & $\begin{array}{l}\text { (Reproducing } \\
\text { females = 2649) }\end{array}$ & & & \\
\hline \multicolumn{2}{|l|}{ Trend index $\left(\mathrm{N}_{2} / \mathrm{N}_{1}\right)$} & & 0.42 & - & - \\
\hline \multicolumn{2}{|c|}{ Generation survival $\left(\mathrm{N}_{3} / \mathrm{N}_{1}\right)$} & & 0.52 & - & - \\
\hline
\end{tabular}


Table.4 Budget of $P$. xylostella on onion intercropped cabbage for first generation

\begin{tabular}{|l|l|l|l|}
\hline \multicolumn{1}{|c|}{ Age interval } & Number / ha & \multicolumn{1}{c|}{ Log No./ha } & \multicolumn{1}{c|}{ 'k' values } \\
\hline Expected Eggs & 10631 & 4.0265 & - \\
\hline Viable Eggs & 10100 & 4.0043 & 0.0222 \\
\hline Early instar larvae & 10100 & 4.0043 & 0.0000 \\
\hline $\begin{array}{l}\text { After mortality due to parasitoidand } \\
\text { unknown reasons - Late instar larvae }\end{array}$ & 8728 & 3.9409 & 0.0634 \\
\hline $\begin{array}{l}\text { After mortality due to parasitoidand } \\
\text { unknown reasons - Pupae }\end{array}$ & 5641 & 3.7513 & 0.1896 \\
\hline After mortality due to parasitoid - Moths & 5298 & 3.721 & 0.0272 \\
\hline Reproducing females & 2649 & 3.4230 & 0.3011 \\
\hline & \multicolumn{3}{|l|}{$\mathrm{K}=0.6035$} \\
\hline
\end{tabular}

Table.5 Key mortality factors of $P$. xylostella on sole cabbage for second generation

\begin{tabular}{|c|c|c|c|c|c|}
\hline Age interval & $\begin{array}{c}\text { Number alive / } \\
\text { ha at the } \\
\text { beginning of } x\end{array}$ & $\begin{array}{l}\text { Factors } \\
\text { responsible } \\
\quad \text { for } d_{x}\end{array}$ & \begin{tabular}{|c} 
Number \\
dying \\
during \\
$x$
\end{tabular} & $\begin{array}{c}d_{x} \text { as } \\
\% \text { of } \\
l_{x}\end{array}$ & $\begin{array}{c}\text { Survival } \\
\text { rate at age } \\
x\end{array}$ \\
\hline $\mathrm{X}$ & $1_{\mathrm{x}}$ & $d_{x} F$ & $d_{x}$ & $100 q_{x}$ & $\mathrm{~S}_{\mathrm{x}}$ \\
\hline Expected eggs & 8230 & Sterility & 411 & 5.00 & \\
\hline Viable eggs & 7819 & - & & & \\
\hline \multicolumn{6}{|l|}{ Larval population } \\
\hline $\begin{array}{l}\text { Early instar larvae } \\
\left(\mathrm{N}_{1}\right)\end{array}$ & 7819 & Cotesia vestalis & 686 & 8.77 & 0.91 \\
\hline \multirow[t]{2}{*}{ Late instar larvae } & 7133 & Cotesia vestalis & 2058 & 28.85 & 0.61 \\
\hline & 5075 & Unknown reasons & 686 & 13.52 & \\
\hline \multirow[t]{2}{*}{ Pupae } & 4389 & Tetrastichussp. & 343 & 7.61 & 0.84 \\
\hline & 4046 & Unknown reasons & 343 & 8.48 & \\
\hline Moths & 3703 & Sex $50 \%$ females & & & \\
\hline Females x $2\left(\mathrm{~N}_{3}\right)$ & 3703 & $\begin{array}{l}\text { (Reproducing } \\
\text { females }=1851)\end{array}$ & & & \\
\hline \multicolumn{2}{|c|}{ Trend index $\left(\mathrm{N}_{2} / \mathrm{N}_{1}\right)$} & & 0.29 & - & - \\
\hline \multicolumn{2}{|c|}{ Generation survival $\left(\mathrm{N}_{3} / \mathrm{N}_{1}\right)$} & & 0.47 & - & - \\
\hline
\end{tabular}


Table.6 Budget of $P$. xylostella on sole cabbage for second generation

\begin{tabular}{|l|l|l|l|}
\hline \multicolumn{1}{|c|}{ Age interval } & Number / ha & Log No./ha & \multicolumn{1}{|c|}{ 'k' values } \\
\hline Expected Eggs & 8230 & 3.9153 & - \\
\hline Viable Eggs & 7819 & 3.8931 & 0.0222 \\
\hline Early instar larvae & 7819 & 3.8931 & 0.0000 \\
\hline $\begin{array}{l}\text { After mortality due to parasitoid } \\
\text { Late instar larvae }\end{array}$ & 7133 & 3.8532 & 0.0399 \\
\hline $\begin{array}{l}\text { After mortality due to parasitoidand } \\
\text { unknown reasons } \\
\text { Pupae }\end{array}$ & 4389 & 3.6423 & 0.2109 \\
\hline $\begin{array}{l}\text { After mortality due to parasitoidand } \\
\text { unknown reasons } \\
\text { Moths }\end{array}$ & 3703 & 3.5685 & 0.0738 \\
\hline Reproducing females & 1851 & 3.2674 & 0.3011 \\
\hline \multicolumn{3}{|l|}{$\mathrm{K}=0.6479$} & \\
\hline
\end{tabular}

Table.7 Key mortality factors of $P$. xylostella on onion intercropped cabbage for second generation

\begin{tabular}{|c|c|c|c|c|c|}
\hline Age interval & $\begin{array}{c}\text { Number alive } \\
\text { /ha at the } \\
\text { beginning of } \\
x\end{array}$ & $\begin{array}{l}\text { Factors } \\
\text { responsible } \\
\text { for }_{d_{x}}\end{array}$ & $\begin{array}{l}\text { Number } \\
\text { dying } \\
\text { during } x\end{array}$ & $\begin{array}{c}d_{x} \text { as } \\
\% \text { of } l_{x}\end{array}$ & $\begin{array}{c}\text { Survival } \\
\text { rate at } \\
\text { age } x\end{array}$ \\
\hline $\mathrm{X}$ & $\mathrm{l}_{\mathrm{x}}$ & $\mathrm{d}_{\mathrm{x}} \mathrm{F}$ & $\mathrm{d}_{\mathrm{x}}$ & $100 q_{x}$ & $S_{\mathrm{x}}$ \\
\hline Expected eggs & 4458 & Sterility & 223 & 5.00 & \\
\hline Viable eggs & 4235 & - & & & \\
\hline \multicolumn{6}{|l|}{ Larval population } \\
\hline $\begin{array}{l}\text { Early instar larvae } \\
\left(\mathrm{N}_{1}\right)\end{array}$ & 4235 & Unknown reasons & 343 & 8.10 & 0.92 \\
\hline Late instar larvae & 3892 & Cotesia vestalis & 1372 & 35.25 & 0.65 \\
\hline Pupae & 2520 & Tetrastichussp. & 343 & 13.61 & \\
\hline Moths & 2177 & Sex $50 \%$ females & - & & \\
\hline Females x $2\left(\mathrm{~N}_{3}\right)$ & 2177 & $\begin{array}{l}\text { (Reproducing } \\
\text { females= 1088) }\end{array}$ & & & \\
\hline \multicolumn{2}{|l|}{ Trend index $\left(\mathrm{N}_{2} / \mathrm{N}_{1}\right)$} & & 0.00 & - & - \\
\hline \multicolumn{2}{|c|}{ Generation survival $\left(\mathrm{N}_{3} / \mathrm{N}_{1}\right)$} & & 0.51 & - & - \\
\hline
\end{tabular}


Table.8 Budget of $P$. xylostella on onion intercropped cabbage for second generation

\begin{tabular}{|l|l|l|l|}
\hline \multicolumn{1}{|c|}{ Age interval } & \multicolumn{1}{|c|}{ Number / ha } & \multicolumn{1}{c|}{ Log No./ha } & \multicolumn{1}{c|}{ 'k' values } \\
\hline Expected Eggs & 4458 & 3.6491 & - \\
\hline Viable Eggs & 4235 & 3.6268 & 0.0223 \\
\hline Early instar larvae & 4235 & 3.6268 & 0.0000 \\
\hline $\begin{array}{l}\text { After mortality due to unknown reasons } \\
\text { Late instar larvae }\end{array}$ & 3892 & 3.5901 & 0.0367 \\
\hline $\begin{array}{l}\text { After mortality due to parasitoid } \\
\text { Pupae }\end{array}$ & 2520 & 3.4014 & 0.1887 \\
\hline $\begin{array}{l}\text { After mortality due to parasitoid } \\
\text { Moths }\end{array}$ & 2177 & 3.3378 & 0.0636 \\
\hline Reproducing females & 1088 & 3.0366 & 0.3012 \\
\hline \multicolumn{3}{|l|}{$\mathrm{K}=0.6125$} \\
\hline
\end{tabular}

Table.9 Key mortality factors of $P$. xylostella on sole cabbage for third generation

\begin{tabular}{|c|c|c|c|c|c|}
\hline Age interval & $\begin{array}{c}\text { Number } \\
\text { alive / ha } \\
\text { at the } \\
\text { beginning } \\
\text { of } x\end{array}$ & $\begin{array}{c}\text { Factors } \\
\text { responsible for } d_{x}\end{array}$ & $\begin{array}{c}\text { Number } \\
\text { dying } \\
\text { during } x\end{array}$ & $\begin{array}{l}d_{x} \text { as } \\
\% \text { of } l_{x}\end{array}$ & $\begin{array}{c}\text { Survival } \\
\text { rate at age } \\
\quad x\end{array}$ \\
\hline $\mathrm{X}$ & $1_{\mathrm{x}}$ & $\mathrm{d}_{\mathrm{x}} \mathrm{F}$ & $d_{x}$ & $100 q_{x}$ & $S_{x}$ \\
\hline Expected eggs & 2401 & Sterility & 120 & 5.00 & \\
\hline Viable eggs & 2281 & - & & & \\
\hline \multicolumn{6}{|l|}{ Larval population } \\
\hline $\begin{array}{l}\text { Early instar larvae } \\
\left(\mathrm{N}_{1}\right)\end{array}$ & 2281 & Cotesia vestalis & 343 & 15.03 & 0.85 \\
\hline Late instar larvae & 1938 & Cotesia vestalis & 343 & 17.70 & 0.82 \\
\hline Pupae & 1595 & Tetrastichussp. & 343 & 21.50 & 0.78 \\
\hline Moths & 1252 & Sex $50 \%$ females & & & \\
\hline Females x $2\left(\mathrm{~N}_{3}\right)$ & 1252 & $\begin{array}{l}\text { (Reproducing } \\
\text { females }=626 \text { ) }\end{array}$ & & & \\
\hline \multicolumn{3}{|l|}{ Trend index $\left(\mathrm{N}_{2} / \mathrm{N}_{1}\right)$} & 0.00 & - & - \\
\hline \multicolumn{3}{|c|}{ Generation survival $\left(\mathrm{N}_{3} / \mathrm{N}_{1}\right)$} & 0.54 & - & - \\
\hline
\end{tabular}


Table.10 Budget of $P$. xylostella on sole cabbage for third generation

\begin{tabular}{|l|l|l|l|}
\hline \multicolumn{1}{|c|}{ Age interval } & Number / ha & Log No./ha & \multicolumn{1}{c|}{ 'k' values } \\
\hline Expected Eggs & 2401 & 3.3803 & - \\
\hline Viable Eggs & 2281 & 3.3581 & 0.0222 \\
\hline Early instar larvae & 2281 & 3.3581 & 0.0000 \\
\hline $\begin{array}{l}\text { After mortality due to parasitoid - Late } \\
\text { instar larvae }\end{array}$ & 1938 & 3.2873 & 0.0708 \\
\hline After mortality due to parasitoid - Pupae & 1595 & 3.2027 & 0.0846 \\
\hline After mortality due to parasitoid - Moths & 1252 & 3.0976 & 0.1051 \\
\hline Reproducing females & 626 & 2.7965 & 0.3011 \\
\hline \multicolumn{3}{|l|}{$\mathrm{K}=0.5838$} \\
\hline
\end{tabular}

The larvae and pupae of diamondback moth were reported to be parasitized by $T$. sokolowskii and A. plutellae in Hebbal area of Bangalore (Jayarathanam, 1977). Cheliah and Srinivasan (1986) reported that A. plutellae parasitizing upto 72 per cent and Tetrastichussokolowskii were found to be dominant larval and pupal parasitoids of $P$. xylostella on cabbage. Bertolaccini et al., (2011) demonstrated that Diadegmainsulare and Oomyzussokolowskii were found to be the most successful parasitoids against $P$. xylostella. Cotesia vestalis was found attracted to blend of sabinene, $n$-heptanal, $\alpha$ pinene, and (Z)-3 hexenyl acetate at ratios 1.8:1.3:2.0:3.0 (Uefune et al., 2012). In South Africa, it is the most efficient species often accounting for more than $80 \%$ of total parasitism levels of $P$. xylostella (Nofemela, 2013; Bopape et al., 2014). As far as Cotesia vestalis and Tetrastichus sp. are concerned the results of the present investigations on parasitoid of $P$. xylostella are in conformity with the results reported by earlier workers.

The population and number of generations of $P$. xylostella were observed to be less on onion intercropped cabbage than on sole crop of cabbage. This could be because of repellent effect of onion on $P$. xylostella. However, there was no any repellent effect of onion on its parasitoid, C. vestalis.
Srinivasan and Krishna (1991) reported that intercropping of non-host crops such as onion, tomatoes and pepper in cabbage could lead to the disruption of lifecycle of $P$. xylostella. Said and Itulya (2003) found that onion has repellent effect on diamondback moth. AsareBediako et al., (2010) recorded less infestation of diamondback moth on cabbage intercropped with onion and tomato. Cai et al., (2011) proved that increase in size and pupal mortality was significantly higher in $P$. xylostella,when Chinese cabbage (Brassica chinensis) was intercropped with garlic (Allium sativum) and lettuce (Lactuca sativa)

Elwell and Mass (1995) reported that tomato and onion released compounds have repellent effect on adult diamondback moth. Renwick (1999) reported that garlic and other plants in the Allium family release strong volatiles which can reduce the attraction of phytophagous insects. Presence of saponin, a feeding deterrent, is a major reason for the low survival of $P$. xylostellaon Barbarea vulgaris (Shinoda et al., 2002; Agerbirk et al., 2003).

\section{References}

Agerbirk, N., Olsen, C.E., Bibby, B.M., Frandsen, H.O., Brown, L.D., Nielsen, J.K. and Renwick, J.A.A. 2003. A saponin correlated with variable 
resistance of Barbarea vulgaris to the diamondback moth Plutella xylostella. J. Chem. Ecol., 29: 1417-1433.

Anonymous. 2017. Statistics: Area and production statistics National Horticulture Board, www.http://nhb.gov.in

Asare-Bediako, E., Addo-Quaye, A.A. and Mohammed, A. 2010. Control of diamondback moth (Plutella xylostella) on cabbage (Brassica oleracea var. capitata) using intercropping with nonhost crops. American J. Food Technol., 5(4): 269-274.

Atwal, A.S. and Bains, S.S. 1974. Applied Animal Ecology. Kalyani publishers, Ludhiana: 128-135.

Bertolaccini, I., Sánchez, D.E., Arregui, M.C., Favaro, J.C. and Theiler, N. 2011. Mortality of Plutella xylostella (Lepidoptera, Plutellidae) by parasitoids in the Province of Santa Fe, Argentina. Revista Brasileira de Entomologia. 55(3): 454-456.

Bhatia, R. and Verma, A.K. 1993. Insect pest complex of cabbage in Himachal Pradesh. J. Insect Sci., 6(2): 297-298.

Bopape, M.J., Nofemela, R.S., Mosiane, M.S. and Modise, D.M. 2014. Effects of a selective and a broad-spectrum insecticide on parasitism rates of Plutella xylostella (L.) (Lepidoptera: Plutellidae) and species richness of its primary parasitoids. African Entomol., 22: 115-126.

Cai, H., Li, S., Ryall, K., You, M. and Lin, S. 2011. Effects of intercropping of garlic or lettuce with Chinese cabbage on the development of larvae and pupae of diamondback moth (Plutella xylostella). African J. Agri. Res., 6(15): 3609-3615.

Cheliah, S. and Srinivasan, K. 1986. Bioecology and management of diamondback moth in India. In: Diamondback moth management, proceedings of first international workshop Taiwan, Taiwan. 11-15 March, 63-67.

Elwell, H. and Mass, A. 1995. Natural pest and disease control. The Natural Farming Network, P. O. box 301, Causeway, Harare, Zimbabwe.
Fletcher, T.B. 1914. Some South Indian insects. Superintendent, Government Press, Madras pp: 565.

Furlong, M.J., Wright, D.J. and Dosdall, L.M. 2013. Diamondback moth ecology and management: problems, progress, and prospect. Annual Rev. Entomol., 58: 517541.

Harcourt, D.G. 1970. Crop life-tables as a pest management tool. The Canadian Entomologist, 102: 950-955.

Harcourt, D.G. 1963. Major mortality factors in the population dynamics of the diamondback moth, Plutellamaculipennis (Curt.) (Lepidoptera: Plutellidae). Memoirs of the Entomological Society of Canada, 32: 55-66.

Harcourt, D.G. 1966. Major factors in survival of the immature stage of Pierisrapae (L.). The Canadian Entomologist, 98: 653-662.

Harcourt, D.G. 1969. The development and use of life-table in study of natural insect population. Annual Rev. Entomol., 14: 175-176.

Hill, D.S. 1975. Agricultural insect-pests of the tropics and their control, Cambridge University Press: 61-78.

Jankowska, B. and Wiech, K. 2006. The composition and role of parasitoids in reducing population densities of diamondback moth Plutella xylostella L. on different cabbage vegetables. J. Plant Protection Res., 46: 275-284.

Jayarathnam, K. 1977. Studies on population dynamics of diamondback moth, Plutella xylostella (L.) and crop loss due to the pest in cabbage. Ph.D. Thesis, University of Agricultural Sciences, Bangalore: 220.

Krishnakumar, H.K., Srinivasan, K. and Sunam, C.L. 1983. Optimum control strategy of cabbage pests from a chemical control trial. Progressive Hort., 18: 104-110.

Morris, R.F. 1959. Single factor analysis in population dynamics. Ecol., 40: 580-588.

Morris, R.F. and Miller, C.A. 1954. Development of life-tables for the spruce budworm. Canadian J. Zool., 32: 283301.

Nofemela, R.S. 2013. A simple method for 
estimating instantaneous levels of endoparasitism of Plutella xylostella (Linnaeus) (Lepidoptera: Plutellidae) by Hymenoptera in the field. African Entomol., 21: 280-286.

Pandey, R. and Raju, S.V.S. 2003. Bioefficiency of some ecofriendly insecticides against diamondback moth, Plutella xylostella. Indian J. Entomol., 65(3): 368-372.

Renwick, J.A.A. 1999. Phytochemical modification of taste: An insect model it. In: H. C. Cutler and S.J. Cutler (eds.), biologically active natural product: Agrochemicals. CRC Press, Boca Raton, USA, pp. 221-229.

Said, M. and Itulya, F.M. 2003. Intercropping and nitrogen management effects on diamondback moth and yields of collards in the highlands of Kenya. African Crop Sci. J., 2: 35-42.

Sarfraz, M. and Keddie, B.A. 2005. Conserving the efficacy of insecticides against Plutella xylostella (L.) (Lep., Plutellidae). J. Appl. Entomol., 129: 149-157.

Sarfraz, M., Keddie, A. and Dosdall, L. 2005. Biological control of the diamondback moth, Plutella xylostella: A review. Biocontrol Sci. Technol., 15(8): 763-789.

Shinoda, T., Nagao, T., Nakayama, M., Serizawa, H., Koshioka, M., Okabe, H. and Kawai, A. 2002. Identification of a triterpenoidsaponin from a crucifer, Barbarea vulgaris, as a feeding deterrent to the diamondback moth, Plutella xylostella. J. Chem. Ecol., 28: 587-599.

Srinivasan, K. and Krishna, M.P.N. 1991.
Indian mustard as a trap crop of major lepidopterous pests of cabbage. Trop. Pest Management, 37: 26-32.

Talekar, N.S. and Shelton, A.M. 1993. Biology, Ecology and Management on diamondback moth. Annual Rev. Entomol., 38: 275-301.

Uefune, M., Choh, Y., Abe, J., Shiojiri, K., Sano, K., and Takabayashi, J. 2012. Application of synthetic herbivoreinduced plant volatiles causes increased parasitism of herbivores in the field. $J$. Appl. Entomol., 136: 561-567.

Verkerk, R. and Wright, D.J. 1996. Multitrophic interactions and management of the diamondback moth: A review. Bull. Entomol. Res., 86: 205-216.

Yadav, D.N., Patel, R.C. and Manjunath, T.M. 1975. Seasonal activity of Apantelesplutellae Kurdj, a larval parasite of Plutella xylostella (L.) at Anand (Gujarat, India). Indian J. Plant Protection, 3(2): 111-115.

Yadav, D.N., Patel, R.C. and Manjunath, T.M. 1979. On the occurrence of new larval parasites of Plutella xylostella (Linn.) in Gujarat. Curr. Sci., 8: 312-313.

Zalucki, M. P., Shabbir, A., Silva, R., Adamson, D., Shu-Sheng, L. and Furlong, M. 2012. Estimating the Economic Cost of One of the World's Major Insect Pests, Plutella xylostella (Lepidoptera: Plutellidae): Just How Long is a Piece of String? J. Economic Entomol., 105(4): 1115-1129.

Zhang, B.C. 1994. Some South Indian insects. Superintendent, Government Press. Madras pp: 565.

\section{How to cite this article:}

Aravindarajan, G., S.R. Dhandge, T. Anandmurthy and Wandhekar, J.E. 2017. Field LifeTables and Key Mortality Factors of Plutella xylostella Infesting Sole and Onion Intercropped Cabbage. Int.J.Curr.Microbiol.App.Sci. 6(5): 591-602. doi: https://doi.org/10.20546/ijcmas.2017.605.068 